\title{
Пренатальна діагностика атріовентрикулярної комунікації в плода як метод прогнозування результату хірургічного лікування вади після народження дитини
}

\author{
Шаповал Л. А. ${ }^{1}$, Куркевич А. К. ${ }^{1}$, Руденко Н. М. ${ }^{1,2}$, Ємець І. М. ${ }^{1}$ \\ ${ }^{1}$ ДУ «Науково-практичний медичний центр дитячої кардіології та кардіохірургії МОЗ України», м. Київ, Україна \\ ${ }^{2}$ Національна медична академія післядипломної освіти імені П. Л. Шупика, м. Київ, Україна
}

\begin{abstract}
Резюме. Атріовентрикулярна комунікація (АВК) є однією з найпоширеніших вроджених вад серця (ВВС), що діагностується пренатально [1-5]. За даними різних досліджень, серед усіх ВВС, діагностованих під час внутрішньоутробного життя плода, АВК становить $17 \%$ [1]. Переривання вагітності та внутрішньоутробна загибель плода значно впливають на цей показник, так як серед усієї вродженої серцевої патології в народжених живими АВК складає лише $4-5 \%[2,4,5]$. Існує багато анатомічних варіантів вади. А часте поєднання вади з додатковими серцевими, позасерцевими та хромосомними аномаліями суттєво впливає як на прогноз для плода з АВК, так і на результат хірургічного лікування вади після народження дитини [5].

Мета. Проаналізувати спектр випадків пренатально діагностованої АВК у плода й оцінити подальший результат хірургічного лікування залежно від анатомічних особливостей вади та асоційованих з нею додаткових серцевих, позасерцевих і хромосомних аномалій.
\end{abstract}

Матеріали і методи. Із січня 2014 року по грудень 2017 року у відділенні пренатальної діагностики ДУ «НПМЦ ДКК МОЗ України» обстежено 4343 вагітних. Під час проведення фетальної ехокардіографії у 1247 плодів діагностовано ВВС, у 215 (17,2 \%) з яких - АВК. Ми проаналізували дані фетальної ехокардіографії у плодів з АВК та порівняли їх з постнатальними даними.

Результати. АВК діагностована у 215 плодів та підтверджена у 120 новонароджених. Середній вік матері склав 29,9 $\pm 5,4$ року (діапазон 17-46). Середній період гестації становив 24,7 $\pm 4,9$ тижня (діапазон 17-39). Каріотип плода на момент первинної консультації був відомий у 45 (20,9\%) випадках, хромосомні аномалії виявлені у 30 (14\%) плодів. АВК без будь-яких інших внутрішньосерцевих вад розвитку відзначалась у 111 $(51,6 \%)$ плодів. Позасерцеві аномалії були виявлені в 104 (48,3 \%) плодів. У 87 (40,5\%) випадках відбулося переривання вагітності. 120 (55,8 \%) вагітностей закінчились строковими пологами та 8 (3,7 \%) - внутрішньоутробною загибеллю плода. 38 випадків внутрішньоутробної загибелі плода в 4 випадках АВК була як ізольована патологія, в інших 4 - у поєднанні з додатковими внутрішньосерцевими вадами розвитку. Iз 120 народжених живими немовлят $63(28,8 \%)$ померли протягом перших місяців життя, не отримавши кардіохірургічної допомоги. Лише 57 (26,5 \%) пацієнтам проведено хірургічне лікування. Із 215 плодів 3 пренатально діагностованою АВК хромосомна патологія спостерігалась у 66 (30,7 \%) новонароджених, у 63 $(29,3 \%)$ з яких був виявлений синдром Дауна.

Спектр анатомічних варіантів ABK, діагностованих пренатально, суттєво відрізнявся від даних, отриманих після народження дитини, зокрема щодо більшої частоти комплексних внутрішньосерцевих вад розвитку, виявлених під час внутрішньоутробного життя плода. У постнатальному періоді АВК частіше траплялась як ізольований варіант патології.

Висновки. Пренатальна ехокардіографія є загальноприйнятим методом ранньої діагностики АВК з високою чутливістю та специфічністю, що дозволяє обгрунтувати та планувати перинатальну тактику ведення вагітності та хірургічне лікування вади в оптимальні строки. Результати нашого дослідження підтверджують велику різноманітність спектра анатомічних варіантів ABK, виявлених під час внутрішньоутробного життя плода. Часто вади поєднуються з додатковими внутрішньосерцевими вадами, рідше - пов'язані 3 хромосомними або позасерцевими аномаліями, проте це передбачає менш сприятливий прогноз подальшого хірургічного лікування через наявність додаткової внутрішньосерцевої патології.

Ключові слова: атріовентрикулярна комунікація, пренатальна діагностика, фетальна ехокардіографія.

Вступ. Атріовентрикулярна комунікація (АВК) є однією з найпоширеніших вроджених вад серця (ВBC), що діагностуються пренатально [1-5]. Серед усіх ВВС, діагностованих під час внутрішньоутробного життя плода, АВК трапляється із частотою 17 \% [1]. Переривання вагітності та внутрішньоутробна загибель плода 
значно впливають на цей показник, оскільки серед усіх вроджених аномалій серця в дітей, народжених живими, АВК складає лише 4-5 \% [2, 4, 5]. Існує багато анатомічних варіантів вади. Окрім цього, часте поєднання вади з додатковими серцевими, позасерцевими та хромосомними аномаліями суттєво впливає як на прогноз для плода з АВК, так і на результат хірургічного лікування вади після народження дитини.

Мета. Проаналізувати спектр випадків пренатально діагностованої АВК у плода та оцінити подальший результат хірургічного лікування залежно від анатомічних особливостей вади та асоційованих із нею додаткових серцевих, позасерцевих і хромосомних аномалій.

Матеріали та методи. За період із січня 2014 по грудень 2017 року у відділенні пренатальної діагностики ДУ «НПМЦ ДКК МО3 України» було обстежено 4343 вагітних. Під час проведення фетальної ехокардіографiї (ЕхоКГ) у 1247 плодів діагностовано ВВС, у 215 $(17,2 \%)$ з яких - АВК. Переважна більшість вагітностей були одноплідними, лише у трьох випадках вагітність була двоплідна. Середній вік матері становив 30,6 \pm 7,0 року, середній термін гестації складав 24,7 \pm 4,2 тижня. У 92 (42,8 \%) випадках діагноз був поставлений до 22 тижнів гестації. Жінки, які вирішили продовжити вагітність, обстежувались повторно в терміні 32 тижні для розробки перинатальної тактики. У випадках якщо спостерігалися ознаки серцевої недостатності в плода, водянки плода, а також порушення ритму серця плода, обстеження вагітних проводили частіше.

Дітей, у яких АВК визначалась як ізольований варіант патології, обстежували після народження у віці 1 місяць. При поєднанні АВК з протоко-залежним легеневим або системним кровотоком обстеження новонароджених проводили в перші години або дні життя.

Комплексне трансабдомінальне ультразвукове (УЗ) обстеження серця та великих судин у плодів проводили на УЗ-апаратах фірми Philips (Philips Ultrasound, Bothell, WA) iU22 та EPIQ 7 за допомогою конвексних датчиків С5-1 або С9-2 із частотою 1-5 МГц або 2-9 МГц. Комплексну трансторакальну ЕхоКГ дітям проводили на УЗ-апаратах Philips IE33 із застосуванням у новонароджених фазованих секторних датчиків S12-10 із частотою 10-12 МГц, дітям старше місяця S8-3 із частотою 3-8 МГц.

Усім плодам було проведено двомірну, кольорову та імпульсну доплерівську ЕхоКГ. М-режим двовимірної ЕхоКГ використовували у випадках порушень серцевого ритму в плода.

Діагноз АВК встановлювали за наявності таких ЕхоКГ-критеріїв, як:

1. Візуалізація спільного АВ з'єднання у вигляді великого отвору посередині серця та відсутність так званого «хреста» серця в 4-камерній проекції.

2. Лінійне (недиференційоване) розташування АВ клапанів у 4-камерній проекції.
3. Візуалізація спільного АВ клапана в проекції по короткій осі лівого шлуночка (ЛШ).

4. Наявність притічного дефекту міжшлуночкової перегородки та відсутність первинної міжпередсердної перегородки в 4-камерній проекції.

5. Зображення подовженого та звуженого вихідного тракту ЛШ у 4-камерній проекції внаслідок аномального розташування кореня аорти.

Комбінованою АВК вважали випадки, коли ця вада в плода поєднувалась із додатковими вадами серця і судин, у разі їх відсутності АВК визначалась як ізольований варіант патології. У випадках із відносно рівними розмірами шлуночків ваду класифікували як збалансовану. При незбалансованій АВК $з$ домінуванням правого шлуночка (ПШ) визначався істотно менший розмір ЛШ, а при домінуванні ЛШ - розміри ПШ були значно меншими. Лівопередсердний ізомеризм діагностували на підставі перериву нижньої порожнистої вени з її продовженням у напівнепарну вену та/або за наявності повної АВ блокади в плода 3 АВК та вісцеро-кардіальною гетеротаксією (шлунок розташований контрлатерально верхівці серця, печінка серединно). Характерними ознаками правопередсердного ізомеризму була складна комбінація внутрішньосерцевих вад розвитку з повною АВК та вісцеро-кардіальною гетеротаксією.

Особливості анатомії серця були визначені за даними пренатальних і постнатальних ЕхоКГ. Для підтвердження синдрому гетеротаксії (СГ) після народження дитини додатково виконували КТ на 16-зрізовому томографі Siemens Somatom Sensation. Позасерцеві аномалії та синдроми були діагностовані чи підтверджені суміжними спеціалістами (дитячий хірург, дитячий невролог, генетик).

У процесі дослідження проаналізували випадки асоційованих серцевих і позасерцевих вад розвитку, їхній зв'язок із хромосомною патологією визначав вплив на пренатальний та антенатальний період. Окрім цього, оцінили результат хірургічного лікування залежно від анатомічних особливостей вади з урахуванням морфології спільного АВ клапана та асоційованих аномалій.

Для статистичного аналізу використовувалась програма SPSS Statistics. Порівняння частот якісних показників у групах проводили шляхом побудови таблиць сполученості $2 \times 2$ із застосуванням критерію хі-квадрат або точного методу Фішера. Рівень достовірності р був двобічний, критерієм статистичної достовірності був $\mathrm{p}<0,05$ та вважався статистично значущим.

Результати та їх обговорення. Із 215 плодів, у яких пренатально діагностована АВК, живими народилося 120 (55,8 \%) дітей. Інформацію про переривання вагітності, випадки внутрішньоутробної загибелі плода та випадки неонатальної смерті отримано під час телефонного опитування жінок. В усіх інших випадках діа- 
гноз підтверджено під час постнатального обстеження.

Каріотип плода на момент первинної консультації був відомий у 45 (20,9\%) випадках. Хромосомні аномалії були виявлені в 30 (14 \%) плодів і частіше спостерігались у тих випадках, де АВК визначалась як ізольований варіант патології (таблиця 1). У 27 (12,6 \%) плодів була виявлена трисомія 21, у $1(0,46 \%)$ - трисомія 13 , у $1(0,46 \%)$ - трисомія 18 , у $1(0,46 \%)$ випадку був діагностований синдром Ді Джорджі.

АВК як ізольована вада серця була діагностована в $111(51,6 \%)$ випадках.

Супутні внутрішньосерцеві аномалії було виявлено в 104 випадках (48,3 \%). Єдина додаткова внутрішньосерцева вада розвитку була діагностована у 15 (7 \%) плодів, дві додаткові аномалії - у $10(4,7 \%)$ випадках. У 78 (36,3 \%) випадках виявлено більше двох внутрішньосерцевих вад розвитку.

Серед супутніх внутрішньосерцевих вад у плода 3 АВК можуть бути такі аномалії, як:

- додаткова ліва верхня порожниста вена, що дренується в розширений коронарний синус - 56 $(26,0 \%)$

- подвійний вихід великих судин із ПШ - $54(25,1 \%)$;

- коарктація аорти (КоАо) - $39(18,1 \%)$;

- тетрада Фалло (ТФ) - 26 (12,1\%);

- транспозиція великих артерій + атрезія легеневої артерії + тотальний аномальний дренаж легеневих вен - $23(9,8 \%)$;

- правостороння дуга аорти - $14(6,5 \%)$;

- атрезія легеневої артерії - 12 (5,6\%);

- множинні дефекти міжшлуночкової перегородки $8(3,7 \%)$;

- перерив нижньої порожнистої вени з ії продовженням у напівнепарну вену - 6 (2,8 \%);

- тотальний аномальний дренаж легеневих вен $5(2,3 \%)$;

- декстрокардія - 5 (2,3\%);

- стеноз (атрезія) аортального клапана - $3(1,4 \%)$;

- інверсія шлуночків - $3(1,4 \%)$;

- частковий аномальний дренаж легеневих вен $2(0,9 \%)$

- судинне кільце - 2 (0,9\%).

Із 29 плодів, у яких пренатально діагностовано СГ, у $23(10,7 \%)$ виявлено правопередсердний ізомеризм і у $6(2,8 \%)$ - лівопередсердний. У плодів із правопередсердним ізомеризмом зазвичай спостерігалась складна комбінація внутрішньосерцевих вад розвитку з повною АВК. Подвійний вихід великих судин із ПШ, мальпозиція великих судин (МВС), атрезія або стеноз легеневої артерії, тотальний аномальний дренаж легеневих вен - спектр додаткових внутрішньосерцевих дефектів, який виявлявся в плодів із правопередсердним ізомеризмом і повною АВК. При лівопередсердному ізомеризмі частіше траплялась неповна АВК, перерив нижньої порожнистої вени з iii продовженням у напівнепарну, в одному випадку неповна АВК поєднувалась із повною атріовентрикулярною блокадою.

У 80 (37,2 \%) плодів АВК поєднувалась із позасерцевими вадами розвитку. Спектр аномалій включав патологію центральної нервової системи, кишковошлункового тракту, кінцівок, лиця й інших органів і систем. У $32(14,9 \%)$ плодів спостерігали комплекс аномалій розвитку в декількох системах органів.

У $87(40,5 \%)$ із 215 випадків вагітність була перервана: в $48(43,2 \%)$ випадках АВК була як ізольований варіант патології, у 37 (35,6\%) - в асоціації із додатковими внутрішньосерцевими вадами розвитку.

У 8 (3,7 \%) випадках вагітність закінчилась внутрішньоутробною загибеллю плода: в 4 випадках АВК була ізольованим варіантом патології, в інших 4 - у поєднанні із додатковими внутрішньосерцевими вадами розвитку. Інформація підтверджена результатами патологоанатомічного дослідження.

У більшості випадків причиною внутрішньоутробної загибелі плода було прогресування водянки плода. Зазвичай цей стан розвивається в плода з АВК та вираженою недостатністю спільного АВ клапана внаслідок структурного порушення його будови [5].

Водянка плода $є$ зловісною ознакою, що неминуче веде до внутрішньоутробної загибелі або постнатальних втрат [3]. В усіх випадках, в який діагностувалась водянка плода, відбулась його внутрішньоутробна загибель.

Значно погіршує перинатальний прогноз і брадикардія в плода, що спостерігалась в одному з випадків внутрішньоутробної загибелі плода із СГ (лівопередсердним ізомеризмом), за якого АВК поєднувалась з повною АВ блокадою. Внаслідок розвитку серцевої недостатності, що обумовлена низьким серцевим викидом, ризик внутрішньоутробної загибелі є дуже високим і в нашому спостереженні склав $100 \%$.

Проаналізувавши групи плодів 3 ізольованою та комбінованою АВК, ми не виявили статистично достовірної різниці в частоті переривання вагітності за наявності ізольованої патології серця $(43,2 \%)$ порівняно з тими, хто мав більш складну анатомію $(35,6 \%)$ (таблиця 1). Проте хромосомні аномалії та супутня позасерцева патологія частіше траплялись у групі плодів з ізольованою АВК.

Із 120 народжених живими немовлят 63 (28,8 \%) померли протягом перших місяців життя, не отримавши кардіохірургічної допомоги. Причиною смерті в більшості випадків було поєднання вади серця з позасерцевою та/або хромосомною патологією, що призвело до виникнення поліорганної недостатності як на етапі адаптації дитини в ранньому неонатальному періоді, так і на етапі лікування супутньої патології.

Хірургічне лікування проведено лише 57 (26,5 \%) пацієнтам (рисунок 1). 


\section{Таблиця 1}

Порівняльна характеристика плодів з ізольованою та комбінованою $A B K(n=215)$

\begin{tabular}{|c|c|c|c|}
\hline Параметри & $\begin{array}{c}\text { АВК } \\
\text { як ізольований варіант патології } \\
(\mathrm{n}=111)\end{array}$ & $\begin{array}{c}\text { АВК } \\
\text { В асоціації з додатковими } \\
\text { внутрішньосерцевими вадами } \\
(\mathrm{n}=104) \\
\end{array}$ & $\mathbf{p}$ \\
\hline Середній вік матері, роки & $30,6 \pm 7,0$ & $30,5 \pm 5,9$ & 0,859 \\
\hline Середній термін гестації, тижні & $24,1 \pm 5,5$ & $25,1 \pm 5,9$ & 0,208 \\
\hline Екстракардіальні аномалії, \% & $49(44,1 \%)$ & $31(29,8 \%)$ & $0,030^{*}$ \\
\hline Хромосомні аномалії, \% & $24(21,6 \%)$ & $6(5,7 \%)$ & $0,001^{*}$ \\
\hline Переривання вагітності, \% & $48(43,2 \%)$ & $37(35,6 \%)$ & 0,251 \\
\hline Внутрішньоутробна загибель плода, \% & $4(3,6 \%)$ & $4(3,8 \%)$ & 0,945 \\
\hline Народжені живими, \% & $59(53,1 \%)$ & $61(58,7 \%)$ & 0,945 \\
\hline $\begin{array}{l}\text { Хромосомні аномалії, діагностовані } \\
\text { після народження, \% }\end{array}$ & $49(44,1 \%)$ & $17(16,3 \%)$ & $0,001^{*}$ \\
\hline Отримали кардіохірургічну допомогу, \% & $37(33,3 \%)$ & $20(19,2 \%)$ & $0,001^{*}$ \\
\hline $\begin{array}{l}\text { Загальна виживаність протягом } \\
\text { трирічного періоду спостереження, \% }\end{array}$ & $31(27,9 \%)$ & $16(15,4 \%)$ & 0,237 \\
\hline
\end{tabular}

Примітка. * - різниця статистично значуща.

Двошлуночкова корекція вади виконана 42 пацієнтам із відносно задовільним результатом у більшості випадків. Синдром Дауна (СД) був виявлений у 30 пацієнтів. У 24 випадках проведена первинна корекція АВК. У 6 випадках із помірною гіпоплазією ЛШ та в 1 випадку із помірною гіпоплазією ПШ корекція вади проведена після звужування легеневої артерії. У 8 випадках, у яких АВК поєднувалась 3 помірною гіпоплазією ЛШ, гіпоплазією висхідної аорти та коарктацією аорти, радикальна корекція виконана після звужування ЛА та усунення коарктації аорти. Трьом дітям, у яких АВК поєднувалась із ТФ, в одному випадку радикальна корекція проведена після балонної ангіопластики клапанного стенозу легеневої артерії (ЛА), в двох інших - після накладання модифікованого системно-легеневого анастомозу Блелока Тауссіг. У 9 випадках діагностована незбалансована ABK, із вираженою гіпоплазією ПШ у 5 випадках і вираженою гіпоплазією ЛШ у 4 випадках. Неможливість проведення двошлуночкової корекції обумовлювала багатоетапність втручань із незадовільним результатом у трьох випадках. Із 27 пацієнтів, яким після народження був підтверджений СГ, у 23 випадках батьки новонароджених дітей відмовилися від запропонованого їм багатоетапного паліативного одношлуночкового шляху хірургічного лікування. Двом пацієнтам із СГ (правопередсердний ізомеризм), у яких АВК поєднувалась із подвійний виходом великих судин із ПШ, МВС, великим дефектом міжшлуночкової перегородки (ДМШП), гіпоплазією ЛШ, великим вторинним ДМПП (гемодинамічно спільним передсердям) та ТАДЛВ, у періоді новонародженності проведена корекція ТАДЛВ та виконано звужування легеневої артерії. У подальшому цим дітям проведено оптимізацію легеневого кровотоку шляхом накладання двонаправленого кавпульмонального анастомозу. Ще одному пацієнту з СГ (правопередсердний ізомеризм), у якого АВК поєднувалась з атрезією легеневої артерії, великим вторинним ДМПП (гемодинамічно спільним передсердям) та ТАДЛВ, на 7-му добу життя проведена корекція ТАДЛВ та оптимізація легеневого кровотоку за допомогою модифікованого системнолегеневого анастомозу Блелока - Тауссіг. Дитина померла на 2 місяці життя від інфекційних ускладнень, що виникли після перенесеної пневмонії. Дівчинці iз СГ (лівопередсердним ізомеризмом) та неповною АВК радикальна корекція проведена у віці 1 року.

У 7 пацієнтів, яким виконана двошлуночкова корекція, на доопераційному етапі за допомогою ЕхоКГ були виявлені прогностично несприятливі особливості будови клапанного та підклапанного апаратів спільного АВ клапана, а саме: дефіцит тканин мостовидних стулок, гіпоплазія лівої латеральної стулки, вкорочення хорд та їх аномальне кріплення до гребеня міжшлуночкової перегородки, аномальне положення папілярних м'язів ЛШ. Ці особливості спричиняли різного ступеня некомпетентність спільного АВ клапана та 3 більшою частотою спостерігались у пацієнтів з нормальним каріотипом, рідше - при поєднанні з СД. У післяопераційному періоді в цих пацієнтів зберігалась тенденція до виникнення передумов розвитку залишкової недостатності сформованих під час корекції АВ клапанів або розвитку обструкції виходу з ЛШ і спостерігалась у трьох та одному випадках відповідно. 


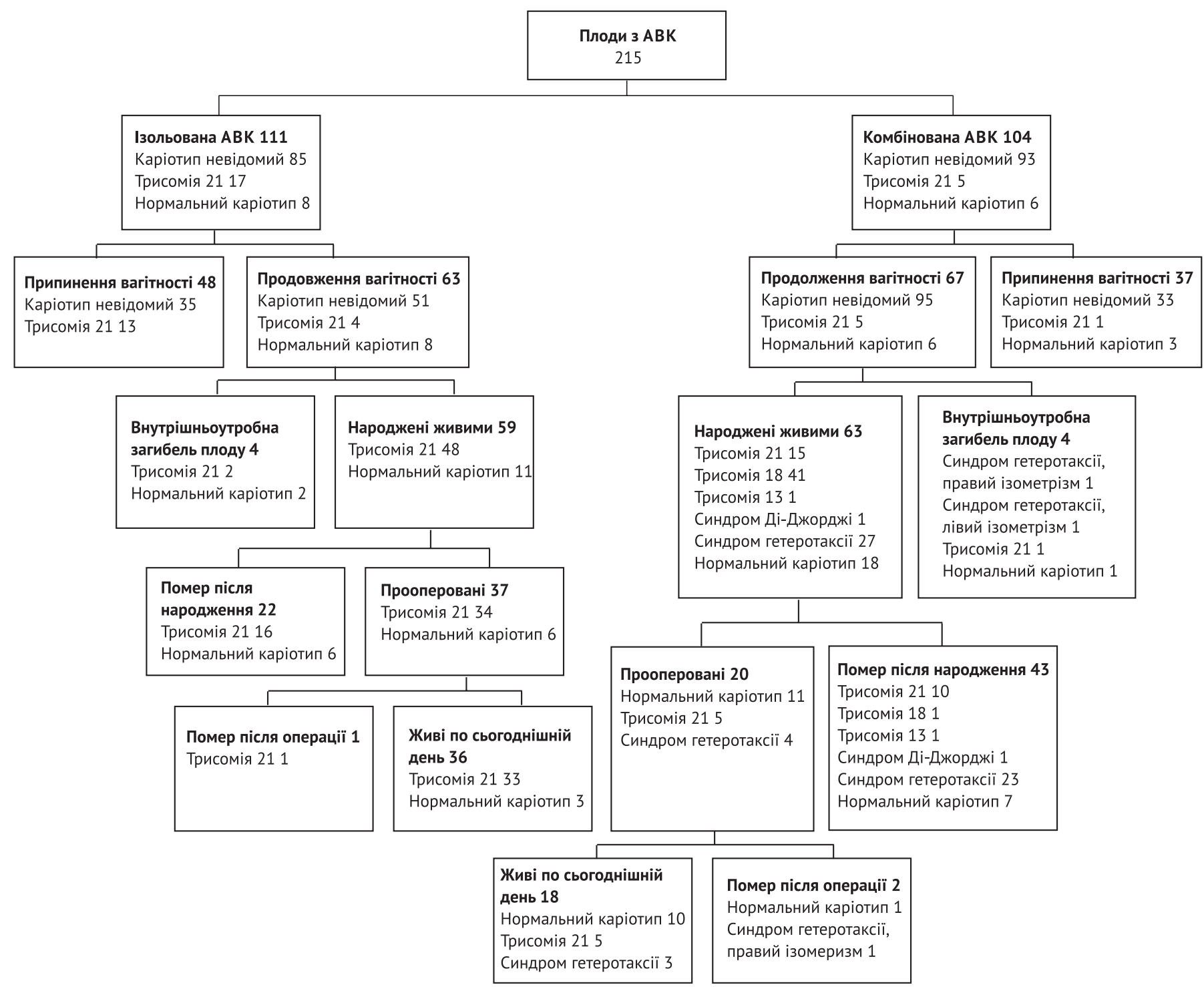

Рисунок 1. Структурна схема остаточного результату для плодів з $A B K$

Загальна виживаність протягом трирічного періоду спостереження склала для пацієнтів з ізольованою ABK 27,9 \%, для пацієнтів з комбінованою АВК $15,4 \%$.

Нині фетальна ЕхоКГ дозволяє досить точно діагностувати тип АВК, морфологію клапанного та підклапанного апарату спільного АВ клапана, асоційовану внутрішньосерцеву патологію та визначити як прогноз для плода з АВК, так і передбачити можливий результат хірургічного лікування вади після народження дитини [5].

У нашому спостереженні спектр анатомічних варіантів АВК, діагностованих пренатально, суттєво відрізнявся від даних, отриманих після народження дитини, особливо щодо більшої частоти комплексних внутрішньосерцевих вад розвитку, виявлених під час внутрішньоутробного життя плода.

У постнатальному періоді АВК частіше траплялась як ізольований варіант патології (таблиця 2).

Результат хірургічного лікування для пацієнтів 3 АВK залежить від анатомічного типу вади та асоційованих із нею додаткових серцевих і позасерцевих вад розвитку $[4,5]$. У $37(64,9 \%)$ пацієнтів, де АВК визначалась як ізольований варіант патології, був застосований відносно простий хірургічний підхід, що складався із закриття септальних дефектів і реконструкції спільного АВ клапана. Корекцію вади виконували на 3-5 місяців життя як у пацієнтів із СД, так і в пацієнтів із нормальним каріотипом, для запобігання виникнення післяопераційних ускладнень, пов'язаних з розви- 
Шаповал Л.А. / Пренатальна діагностика атріовентрикулярної комунікації в плода як метод прогнозування...

Таблиця 2

Характеристика пацієнтів, яким проведено хірургічне лікування $(n=57)$

\begin{tabular}{|c|c|c|c|c|c|c|c|}
\hline \multicolumn{3}{|c|}{$\begin{array}{c}\text { АВК як ізольована патологія } \\
\mathrm{n}=37\end{array}$} & \multicolumn{5}{|c|}{$\begin{array}{l}\text { АВК в асоціації з додатковими внутрішньосерцевими вадами розвитку } \\
n=20\end{array}$} \\
\hline & СД & HK & & Додаткові внутрішньосерцеві вади & СД & HK & $\mathrm{C \Gamma}$ \\
\hline \multirow[t]{6}{*}{ Повна АВК } & \multirow[t]{6}{*}{23} & \multirow[t]{6}{*}{2} & \multirow[t]{6}{*}{ Повна АВК } & KoAo & 1 & 4 & \\
\hline & & & & ТФ & 2 & 1 & \\
\hline & & & & Клапанний стеноз ЛА & & 1 & \\
\hline & & & & Подвійний вихід великих судин з ПШ & 2 & & \\
\hline & & & & $\begin{array}{l}\text { Подвійний вихід } \\
\text { великих судин з ПШ + гіпоплазія ЛШ + АЛА } \\
+ \text { ТАДЛВ }\end{array}$ & & & 1 \\
\hline & & & & $\begin{array}{l}\text { Подвійний вихід великих судин з ПШ + } \\
\text { гіпоплазія ЛШ + МВС + ТАДЛВ }\end{array}$ & & & 2 \\
\hline Неповна АВК & & 7 & Неповна АВК & KoAo & & 2 & 1 \\
\hline \multirow[t]{2}{*}{ Проміжна ABK } & \multirow[t]{2}{*}{2} & \multirow[t]{2}{*}{3} & \multirow[t]{2}{*}{$\begin{array}{l}\text { Проміжна } \\
\text { АВК }\end{array}$} & $\begin{array}{l}\text { КоАо } \\
\text { Клапанний стеноз легеневої артерії }\end{array}$ & 1 & 1 & \\
\hline & & & & Множинні ДМШП & & 1 & \\
\hline
\end{tabular}

Примітка. НК - нормальний каріотип.

тком легеневої гіпертензії. Цей вид ускладнень частіше спостерігався в минулому у випадках із затримкою хірургічного лікування, переважно в дітей із СД, у яких існує більш швидка тенденція до розвитку легеневого судинного обструктивного захворювання протягом першого року життя.

Морфологія спільного АВ клапана суттєво впливає на результат хірургічного лікування [4]. Негативним прогностичним фактором віддаленого хірургічного результату є аномальна будова спільного АВ клапана та ступінь його недостатності $[4,5]$. Проте можливість проведення, вид хірургічного лікування та остаточний прогноз визначає саме супутня внутрішньосерцева патологія. У таких випадках передбачається більш складний хірургічний підхід, часом багатоетапний, що має менш сприятливий прогноз.

Хромосомні аномалії також часто траплялись у наших пацієнтів і найбільш поширеною серед них була трисомія 21. Частота цієї асоціації сягає $50 \%$ у деяких звітах [2, 4]. У нашому спостереженні відсоток плодів iз хромосомними аномаліями, що народилися живими, склав 30,7 \%. Трисомія 21 спостерігалась у 29,7 \% випадках. Із загальної кількості пацієнтів із СД в 23 (40,4 \%) випадках була діагностована повна АВК без додаткових внутрішньосерцевих вад розвитку, що дозволило таким дітям провести первинну хірургічну корекцію вади у віці 3-5 місяців. Неповна та проміжна АВК частіше діагностувались у хворих без СД (14\% та 8,8\% відповідно).

Трисомія 18 спостерігалась у випадку поєднання АВК з подвійним відходженням великих судин від ПШ, великим ДМШП та МВС. Крім того, у дитини були виявлені патологія центральної нервової системи, аномалії лицьового скелета та двосторонній гідронефроз, внаслідок якого на 4 добу життя в дитини виникла гостра ниркова недостатність. Ще в 1 пацієнта була діагностована трисомія 13. Так само, як і в попередньому випадку, АВК поєднувалась зі складним комплексом внутрішньосерцевих дефектів і тяжкою позасерцевою патологією, що призвело до смерті дитини в ранньому неонатальному періоді. Ще в 1 випадку в пацієнта 3 декстракардією був діагностований синдром Ді Джорджі. АВК поєднувалась $з$ атрезією легеневої артерії. Із супутньої позасерцевої патології в дитини посмертно була діагностована атрезія трахеї.

ABK може бути частиною і інших синдромів, таких як Ellis - Van Creveld, VACTRL, CHARGE, Cornelia de Lange та Goldenhar [2]. У пацієнтів, які були включені в наше дослідження, не було виявлено ніяких стигм, що свідчили б про ці синдроми.

У багатьох дослідженнях поєднання АВК з екстракардіальними аномаліями під час внутрішньоутробного життя плода трапляється з частотою від 13 до $72 \%$ та може свідчити про можливість генетичних синдромів [3]. Позасерцева патологія була виявлена в $37 \%$ наших випадків із більшою частотою в тих плодів, в яких не спостерігалось додаткових внутрішньосерцевих вад розвитку: 44,1 \% випадків у групі ізольованої АВК та в 29,8 \% випадків у групі комбінованої АВК $(\mathrm{p}=0,003)$.

У нашому спостереженні загальна виживаність протягом трирічного періоду спостереження була гіршою в групі плодів, де АВК була в поєднанні з додатковими внутрішньосерцевими вадами розвитку та склала 
15,4 \%, у порівнянні з групою плодів, де АВК визначалась як ізольований варіант патології та становила $27,9 \%$.

\section{Висновки}

Пренатальна ехокардіографія є загальноприйнятим методом ранньої діагностики АВК із високою чутливістю та специфічністю, що дозволяє обгрунтувати та планувати перинатальну тактику ведення вагітності та хірургічне лікування вади в оптимальні строки. Результати нашого дослідження підтверджують велику різноманітність спектра анатомічних варіантів АВК, виявлених під час внутрішньоутробного життя плода. Часто вади поєднуються 3 додатковими внутрішньосерцевими вадами, рідше - пов'язані з хромосомними або позасерцевими аномаліями, проте це передбачає менш сприятливий прогноз подальшого хірургічного лікування через наявність додаткової внутрішньосерцевої патології.

\section{Список використаних джерел References}

1. Craig B. Atrioventricular septal defect: from fetus to adult. Heart. 2006 Dec;92(12):1879-85. https://doi. org/10.1136/hrt.2006.093344

2. Allan LD, Sharland GK, Chita SK, Lockhart S, Maxwell DJ. Chromosomal anomalies in fetal congenital heart disease. Ultrasound Obstet Gynecol. 1991 Jan 1;1(1):8-11. https://doi.org/10.1046/j.1469-0705.1991.01010008.x

3. Huggon IC, Cook AC, Smeeton NC, Magee AG, Sharland GK. Atrioventricular septal defects diagnosed in fetal life: associated cardiac and extra-cardiac abnormalities and outcome. J Am Coll Cardiol. 2000 Aug;36(2):593-601.

4. Calkoen EE, Hazekamp MG, Blom NA, Elders BB, Gittenberger-de Groot AC, Haak MC, etal. Atrioventricular septal defect: From embryonic development to long-term follow-up. Int J Cardiol. 2016 Jan 1;202:784-95. https:// doi.org/10.1016/j.ijcard.2015.09.081

5. Beaton AZ, Pike JI, Stallings C, Donofrio MT. Predictors of repair and outcome in prenatally diagnosed atrioventricular septal defects. J Am Soc Echocardiogr. 2013 Feb;26(2):20816. https://doi.org/10.1016/j.echo.2012.11.007

\title{
Prenatal Diagnosis of Atrioventricular Communication in the Fetus as a Method of Predicting the Outcome of Surgical Treatment after the Child's Birth
}

\author{
Shapoval L. A., Kurkevych A. K, Rudenko N. M., Yemets I. M. \\ ${ }^{1}$ Ukrainian Children's Cardiac Centre, Kyiv, Ukraine \\ ${ }^{2}$ Shupyk National Medical Academy of Postgraduate Education, Kyiv, Ukraine
}

\begin{abstract}
Atrioventricular communication (AVC) is one of the most common heart diseases diagnosed prenatally (1-5). According to various studies, among all of congeninal heart diseases diagnosed in fetus, AVC accounts for $17 \%$. Abortion and fetal death significantly affect this indicator, as among all the congenital cardiac abnormalities AVC accounts for only $4-5 \%$ in live births $(4,6)$. There are many anatomical variants of the defect. And frequent combination of the defect with additional cardiac, extracardiac and chromosomal abnormalities significantly impacts both the prognosis for the fetus with AVC and the outcome of surgical treatment of the defect after birth.

The aim. To analyze the range of cases of prenatally diagnosed AVC in the fetus and evaluate further outcome of surgical treatment, depending on the anatomical features of the anomaly and associated additional cardiac, extracardiac and chromosomal abnormalities.

Materials and methods. From January 2014 to December 2017, 4343 pregnant women were screened at the Prenatal Diagnostics Department of the UCCC of the Ministry of Health of Ukraine. During fetal echocardiography, 1247 fetuses were diagnosed with congenital heart defects, $215(17.2 \%)$ of them had AVC. We analyzed the data of fetal echocardiography in fetuses with AVC and compared them with postnatal data.

Results. AVC was diagnosed in 215 fetuses and confirmed in 120 newborns. The average age of the mother was $29.9 \pm 5.4$ years (range 17-46). The average gestation period was $24.7 \pm 4.9$ weeks (range 17-39). At the time of primary consultation, fetal cariotype was known in $45(20.9 \%)$ cases, chromosomal abnormalities were detected in 30 (14\%) of fetuses. AVC without any other intracardiac malformations was revealed in $111(51.6 \%)$ of the fetuses. Extracardiac anomalies were detected in $104(48.3 \%)$ of the fetuses. In 87 (40.5\%) cases, there was an abortion. One hundred twenty (55.8\%) pregnancies ended with term birth, and in 8 (3.7\%) cases fetal death was reported. Of 8 cases of fetal death, in 4 cases AVC was an isolated pathology, in the other 4 it was combined with additional intracardiac defects. Of the 120 born alive, $63(28.8 \%)$ infants died during the first months of life without receiving cardiac surgery. Only $57(26.5 \%)$ patients had surgical treatment. Of 215 fetuses with prenatally diagnosed AVC, chromosomal pathology was detected in 66 (30.7 \%) newborns, 63 (29.3\%) of whom had Down syndrome.

The spectrum of anatomical variants of AVC diagnosed prenatally significantly differed from the data obtained after the birth of a child, especially with regard to the higher incidence of complex intracardiac defects found in fetus. In the postnatal period, AVC was more likely to be seen as an isolated variant of the pathology.
\end{abstract}


In our observation, chromosomal abnormalities associated with AVC were detected in 66 (30.7\%) newborns, 63 (29.3 $\%)$ of them had Down syndrome $(\mathrm{p}=0.001)$. Other heart defects and extracardiac pathology were diagnosed in $48.3 \%$ and $37.2 \%$ of cases, respectively. The survival of fetuses with isolated and combined AVC was $53.1 \%$ and $58.7 \%$. Of the 120 born alive, $28.8 \%$ of infants died during the first months of life.

Surgical treatment was performed in only $26.5 \%$ of patients $(p=0.001)$. The overall survival rate during the three-year follow-up period was $27.9 \%$ for patients with isolated AVC and $15.4 \%$ for patients with combined AVC.

Conclusion. Our data confirm a large variety of the spectrum of anatomical variants of AVC found in fetus. AVC frequently combines with additional intracardiac defects, and less frequently is associated with chromosomal or extracardiac anomalies, however, this suggests less favorable prognosis for further surgical treatment, mainly in the presence of additional intracardiac pathology.

Keywords: atrioventricular communication, prenatal diagnosis, fetal echocardiography.

Стаття надійшла в редакцію 18.04.2019 р. 